\title{
WORLD FOOD CRISIS AND UKRAINIAN OPORTUNITIES IN SOLVING THIS PROBLEM
}

\author{
Taras CHIPKO \\ Institute of Geography, National Academy of Science of Ukraine, Kyiv \\ tarasnauka2015@ukr.net
}

\begin{abstract}
Relevance of the study is resulting from an ever-growing shortage of food in the world and increased demand for it due to the rapid growth of population and limited land suitable for growing crops. In this regard the purpose of this paper is to analyze the situation in cereal market in developing countries and the identification of effects caused by insufficient volumes of its production. The objectives of this article are: analysis of the situation on world food markets (e.g. cereal); territorial peculiarities of the food crisis; the development opportunities of agricultural products in Ukraine due to the increased export of agricultural products in the world; identifying potential markets for Ukrainian agricultural products and analysis of the potential of Ukrainian exports of agricultural products. The documents of Food and Agriculture Organization (FAO), UNO, international legal documents, analytical sources of Internet have been processed for writing this paper. Statistical method has been applied for considering the dynamics of wheat and corn in Ukraine. These data, as well as the data for consumption and import of grain crops in developing countries and the volume of exported grain to these countries, comprises the basis for conclusion that Ukraine has a strong export potential, but doesn't used it completely.
\end{abstract}

Key words: food crisis, production and utilization of grains, undernourished people, export potential, wheat and maize, commodity markets, investments.

UDC: 911.3

\section{ПРОДОВОЛЬЧА КРИЗА У СВІТІ І МОЖЛИВОСТІ УКРАЇНИ В ЇЇ ВИРІШЕННІ}

Tарас ЧІпко

Інститут географії Начіональної академії наук України, Київ tarasnauka2015@ukr.net

\begin{abstract}
Анотація: Актуальність дослідження обумовлена постійно зростаючим дефіцитом продовольства в світі та збільшенням попитуна нього внаслідокшвидкого зростання чисельності населення Землі і обмеженості земель, придатнихдля вирощування сільгоспкультур. У зв'язку з цим метою даної статті $\epsilon$ аналіз ситуації на зерновому ринку у країнах, що розвиваються, та виявлення наслідків, обумовлених недостатнім обсягом його виробництва. Для написання статті опрацьовані документи продовольчої та сільськогосподарської організації (ФАО), ООН, міжнародні правові документи, аналітичні джерела Інтернет. Для розгляду динаміки виробництва пшениці і кукурудзи в Україні використано статистичний метод. На основі цих даних, а також обсягів споживання та імпорту зернових культур у країнах, що розвиваються, і обсягів експортованого зерна у ці країни зроблено висновок про наявність потужного експортного потенціалу України і невикористання його в повній мірі.

Ключові слова: продовольча криза, виробництво і споживання зерна, населення, яке недоїдає, експортний потенціал, пшениця і кукурудза, ринки збуту, інвестиції
\end{abstract}

Удк: 911.3

Вступ. Постановка проблеми. Забезпечення народонаселення світу продовольством - одна 3 найгостріших проблем людства. На початку XXI ст. у зв'язку зі стрімким зростанням чисельності населення у світі, обмеженими земельними ресурсами для виробництва сільгоспкультур у сукупності 3 неминучими процесами деградації грунтів, опустелюванням, збільшенням площ сільгоспугідь під технічні культури тощо проблема забезпечення необхідною кількістю продовольства окремо взятої особи, країни і світової продовольчої безпеки загалом набуває глобального масштабу.

Для ii вирішення недостатньо зусиль окремих держав, а потрібне добре налагоджене співробітництво всіх країн, які мають можливості i передумови для нарощування виробництва продовольства. Завдяки потужному потенціалу сільського господарства, Україна має великі

(C) T. Чіпко можливості для вагомого внеску у вирішення продовольчої проблеми у світі. Володіючи майже третиною світових запасів чорноземів та більш як $25 \%$ орних земель в Європі, вона при збільшенні врожайності основних сільгоспкультур та досягненні середньоєвропейських показників виробництва 31 га здатна забезпечити продовольством понад 1/3 голодуючого населення у світі.

Аналіз останніх досліджень і публікацій. Широкий спектр досліджень 3 проблематики розвитку АПК України та іï регіонів здійснено в працях багатьох українських вчених, зокрема М. Паламарчука, Г. Балабанова,Я. Кирпуша,М. Книш, С. Малюка, В.Нагірної, Л.Мармуль, .Пушкара, В. Семенова, О. Самохвалова, Р. Язиніної та багатьох інших. Дослідження особливостей розвитку АПК України та її регіонів в сучасних умовах проводять В. Нагірна, Я. Олійник, С. Іщук та інші.

Дослідженням невикористаних можливостей виходу України на світові продовольчі ринки займа- 
лися передусім вчені економічних та аграрних наук (І. Кириленко та В. Дем'янчук). Всебічному вивченню внутрішніх та зовнішніх агропродовольчих ринків України, суспільно-географічній оцінці орієнтації АПК України на зовнішній ринок, аналізу основних зовнішньоекономічних векторів агропродовольчого ринку України присвячені праці І.Г. Кавецького.

Однак, незважаючи на численні дослідження 3 різноманітних аспектів сучасного стану i перспектив розвитку АПК України, багато аспектів даного питання залишаються досі недостатньо дослідженими. Особливо актуальним є дослідження можливостей АПК України в контексті інтеграції держави до світових та регіональних продовольчих ринків і підписання угоди про асоціацію з СС.

Формулювання цілей статті. Постановка завдання. Завданнями цієї статті є: 1) аналіз ситуації на світових продовольчих ринках (зокрема iз зерновими культурами); 2) аналіз територіальних особливостей проявів продовольчої кризи; 3) аналіз можливостей розвитку продукції АПК України у зв'язку зі збільшенням експорту сільськогосподарської продукції в світі; 4) виявлення потенційних ринків збуту української сільгосппродукції; 5) аналіз потенційних можливостей українського експорту сільгосппродукції.

Виклад основного матеріалу. Забезпеченість населення світу достатньою кількістю продовольства $є$ однією 3 найголовніших проблем сучасності i має не менш важливе значення, ніж забезпечення населення світу необхідною кількістю водних і енергетичних ресурсів. Світові тенденції такі, що стратегічне значення продовольства порівнюють нині 3 фінансовими ресурсами та енергетичною безпекою.

Так, на Римській зустрічі Загальної ради Міжнародного фонду сільського господарства
(IFAD) 2012 р. наголошувалося, що продовольча та енергетична кризи - набагато серйозніші виклики для людства, ніж економічна та фінансова, оскільки (окрім негативних соціальних та економічних наслідків) можуть спричинити i політичну нестабільність у світі. Відтак продовольча безпека повинна й надалі залишатися пріоритетним завданням для міжнародної спільноти. Адже бідність та голод - основа багатьох світових проблем [1].

Хоча сумарно нині у світі виробляється достатньо продовольства для забезпечення зростаючих потреб людства, однак його не вистачає у регіонах з високим рівнем соціально-економічних ризиків, зокрема 3 високими показниками природного приросту населення.

Так, за даними ФАО, виробництво зернових культур 2013 р. становило 2,53 млрд. т, а споживання - 2,42 млрд. Головними їхніми виробниками були країни Азії, частка яких у світовому валовому зборі зерна становила близько 50\%. Однак загальні обсяги виробництва зерна у цьому регіоні, як і в країнах Африки і Центральної Америки, не забезпечували їхніх потреб на 100\%.

Загалом рівень самозабезпечення зерном (співвідношення загального обсягу виробництва до загальної кількості його споживання) країн Центральної Америки, Африки та Азії становив 62; 71 і 94\%. При цьому країни Північної Африки (Алжир, Сгипет, Судан), Близького Сходу (Ірак), Південної Америки (Колумбія, Венесуела, Перу) забезпечують власні потреби зерном трохи більш як на $30-50 \%$ від загальних обсягів споживання, Японія і Південна Корея- - на 20-30\%, а Саудівська Аравіяменш як на $10 \%$.

В той же час, хоч країни Південної Америки загалом і забезпечують себе зерном у необхідному обсязі, однак рівень самозабезпечення деяких

М.Н. Т

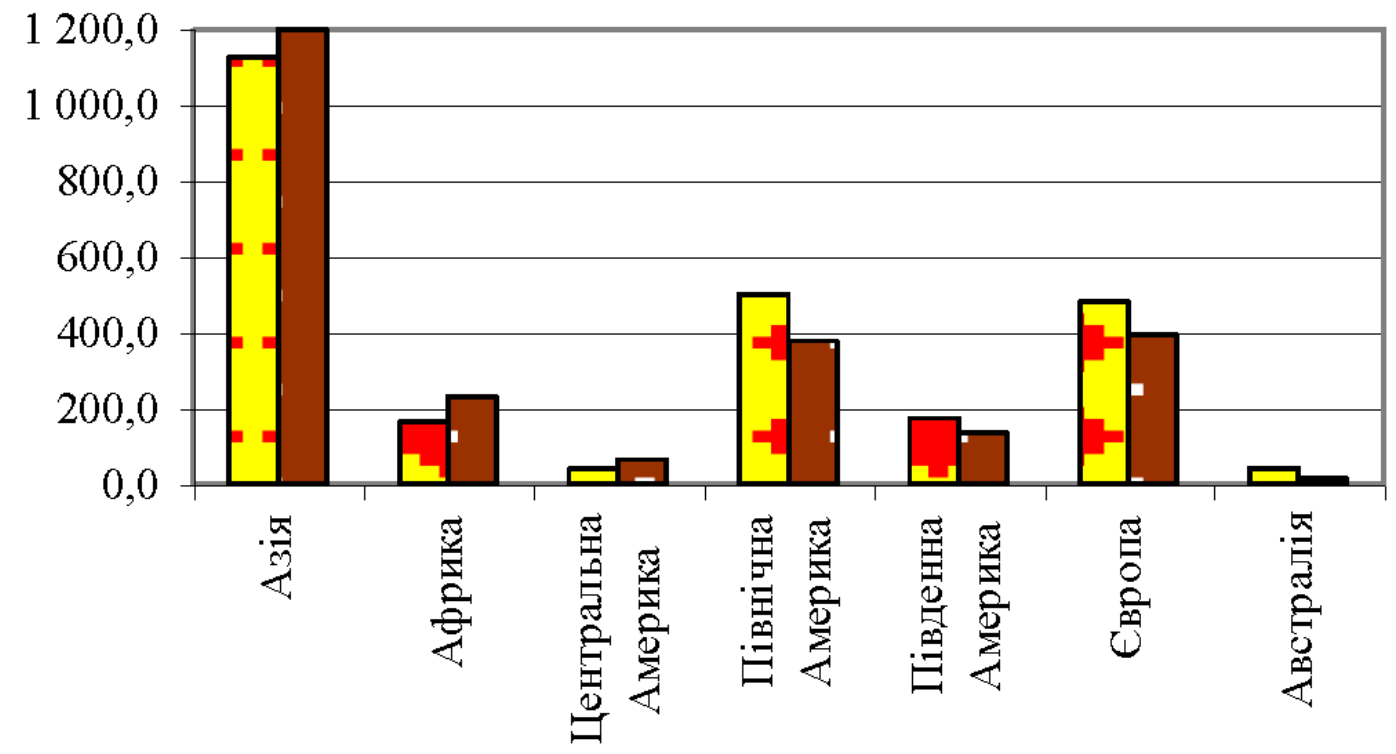

口 Виробництво 口 Споживання

Рис.1. Виробництво і споживання зерна у регіонах світу, 2013 р. 
Таблиия 1

Виробництво, споживання і забезпеченість зерновими культурами у 2013p.

\begin{tabular}{|c|c|c|c|c|c|c|c|c|c|}
\hline & \multicolumn{3}{|c|}{ Зернові культури } & \multicolumn{3}{|c|}{ Пшениця } & \multicolumn{3}{|c|}{ Кукурудза } \\
\hline & $\begin{array}{c}\text { Вироб- } \\
\text { ництво, } \\
\text { млн. т }\end{array}$ & $\begin{array}{l}\text { Спожи- } \\
\text { вання, } \\
\text { млн. т }\end{array}$ & $\begin{array}{c}\text { Рівень } \\
\text { забезпе- } \\
\text { ченості } \\
\end{array}$ & \begin{tabular}{|c|} 
Виробни- \\
цтво, млн. \\
т
\end{tabular} & $\begin{array}{l}\text { Спожи- } \\
\text { вання, } \\
\text { млн. т }\end{array}$ & $\begin{array}{c}\text { Рівень } \\
\text { забезпе- } \\
\text { ченості } \\
\end{array}$ & $\begin{array}{c}\text { Вироб- } \\
\text { ництво, } \\
\text { млн. т }\end{array}$ & $\begin{array}{l}\text { Спожи- } \\
\text { вання, } \\
\text { млн. т }\end{array}$ & $\begin{array}{c}\text { Рівень } \\
\text { забезпе- } \\
\text { ченості } \\
\end{array}$ \\
\hline Азія & 1125,1 & 1199,4 & 0,94 & 318,6 & 363,2 & 0,88 & 304,5 & 333,1 & 0,91 \\
\hline Китай & 490,6 & 488,1 & 1,01 & 121,9 & 125,4 & 0,97 & 218,5 & 209,1 & 1,05 \\
\hline Індія & 243,3 & 220,6 & 1,1 & 93,5 & 85,8 & 1,09 & 24,4 & 18,5 & 1,3 \\
\hline Пакистан & 36,1 & 32,5 & 1,11 & 24,2 & 24,4 & 0,99 & 4,5 & 4,4 & 1,02 \\
\hline Іран & 20,3 & 29,5 & 0,69 & 14 & 16,7 & 0,84 & 1,3 & 5,4 & 0,27 \\
\hline Ірак & 4,7 & 9,2 & 0,51 & 3,3 & 6,1 & 0,54 & - & - & - \\
\hline $\begin{array}{l}\text { Саудівська } \\
\text { Аравія }\end{array}$ & 1,0 & 16,1 & 0,06 & 0,6 & 3,7 & 0,16 & - & - & - \\
\hline Туреччина & 37,1 & 38,4 & 0,97 & 22,1 & 22,5 & 0,98 & 5,9 & 6,4 & 0,92 \\
\hline Бангладеш & 38,1 & 41,0 & 0,93 & 1,4 & 3,7 & 0,38 & - & - & - \\
\hline Таїланд & 30,5 & 22,0 & 1,39 & 0 & 2 & 0 & 5,1 & 4,4 & 1,16 \\
\hline B'єтнам & 34,5 & 31,7 & 0,92 & - & - & - & 5,2 & 7 & 0,74 \\
\hline Малайзія & - & - & - & - & - & - & 0,1 & 3,8 & 0,03 \\
\hline Індонезія & 63,4 & 74,0 & 0,86 & 0 & 7 & 0 & 18,5 & 21,3 & 0,87 \\
\hline Філіппіни & 19,7 & 25,5 & 0,77 & 0 & 3,4 & 0 & 7,3 & 7,8 & 0,94 \\
\hline Японія & 8,8 & 33,1 & 0,27 & 0,8 & 6,4 & 0,13 & 0 & 14,8 & 0 \\
\hline $\begin{array}{l}\text { Південна } \\
\text { Корея }\end{array}$ & 4,5 & 18,4 & 0,22 & 0 & 4,3 & 0 & 0,1 & 9,3 & 0,01 \\
\hline Африка & 163,2 & 230,5 & 0,71 & 27,6 & 65,8 & 0,42 & 70,7 & 83,7 & 0,93 \\
\hline Марокко & 9,9 & 14,3 & 0,69 & 7 & 8,9 & 0,79 & 0,2 & 2,2 & 0,09 \\
\hline Алжир & 4,9 & 15,1 & 0,32 & 3,3 & 9,7 & 0,34 & 0 & 3,3 & 0 \\
\hline Туніс & - & - & - & 1 & 3 & 0,33 & & & \\
\hline Сгипет & 19,5 & 37,3 & 0,52 & 8,8 & 19,2 & 0,46 & 5,7 & 13,2 & 0,43 \\
\hline Ефіопія & 23,6 & 22,1 & 1,07 & 4 & 4,5 & 0,89 & 7,6 & 7 & 1,09 \\
\hline Кенія & - & - & - & - & - & - & 3,4 & 4,1 & 0,83 \\
\hline Нігерія & 21,4 & 27,0 & 0,79 & 0,1 & 3,5 & 0,03 & 10,4 & 9,9 & 1,05 \\
\hline ПАР & 14,9 & 16,5 & 0,9 & 1,9 & 3,3 & 0,58 & 12,5 & 11,3 & 1,11 \\
\hline \begin{tabular}{|l|} 
Центральна \\
Америка \\
\end{tabular} & 40,8 & 48,4 & 0,62 & 3,5 & 10,7 & 0,33 & 26,9 & 40,9 & 0,66 \\
\hline Куба & - & - & - & 0 & 0,8 & 0 & - & - & - \\
\hline Мексика & 34,1 & 48,4 & 0,71 & 3,5 & 6,9 & 0,5 & 22,4 & 31,4 & 0,71 \\
\hline \begin{tabular}{|l|} 
Південна \\
Америка \\
\end{tabular} & 173,3 & 134,8 & 1,29 & 19,1 & 26,5 & 0,72 & 123,2 & 81,1 & 1,5 \\
\hline Бразилія & 97,2 & 75,8 & 1,28 & 5,7 & 11,3 & 0,5 & 80,5 & 52,5 & 1,53 \\
\hline Аргентина & 48,1 & 18,7 & 2,57 & 9,2 & 5,5 & 1,67 & 29 & 9,1 & 3,2 \\
\hline Чилі & 3,6 & 6,0 & 0,6 & 1,5 & 2,3 & 0,65 & 1,5 & 2,3 & 0,65 \\
\hline Перу & 4,2 & 8,2 & 0,51 & 0,2 & 1,9 & 0,11 & 1,7 & 3,6 & 0,47 \\
\hline Колумбія & 3,9 & 9,9 & 0,39 & 0 & 1,4 & 0 & 1,9 & 5,4 & 0,35 \\
\hline Венесуела & 3,4 & 7,4 & 0,46 & 0 & 1,8 & 0 & 2,2 & 4,2 & 0,52 \\
\hline
\end{tabular}

Складено і розраховано за [3] 


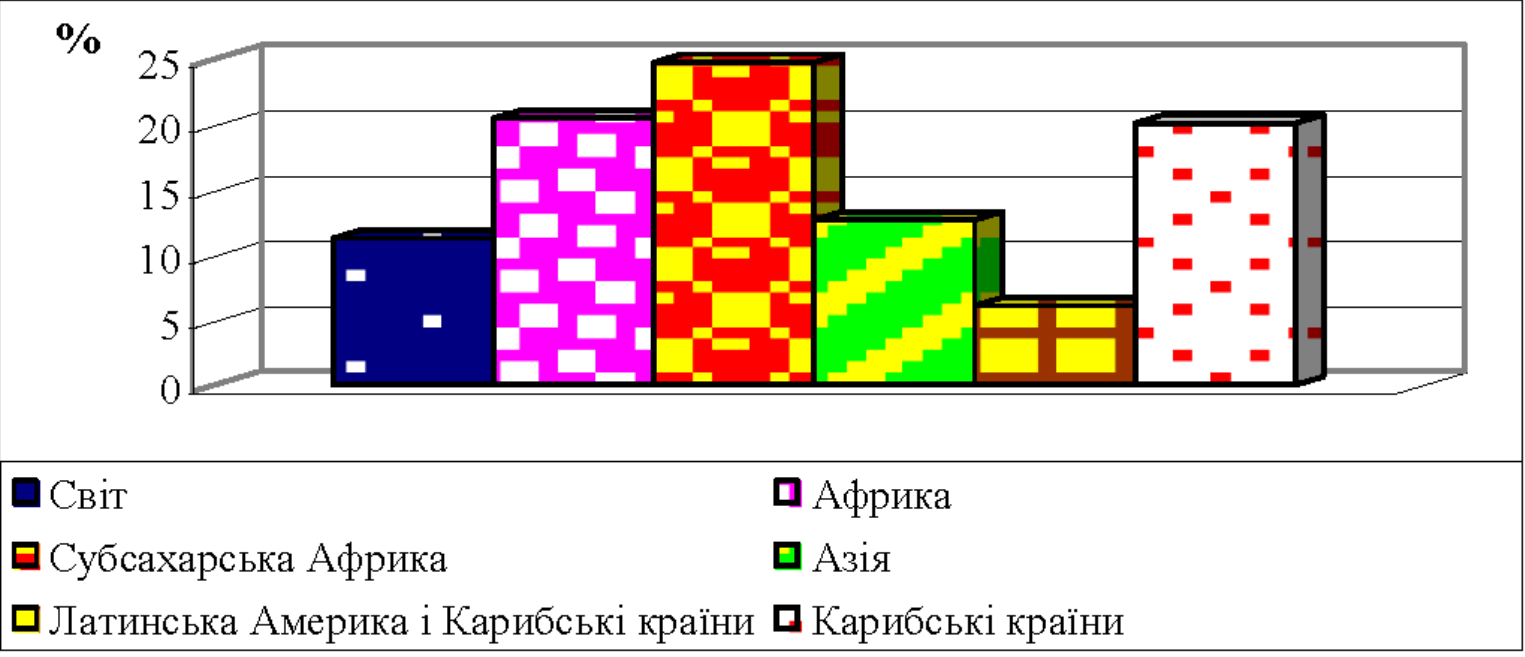

Рис.2. Регіони світу. Частка людей, які недоїдають, у загальній чисельності населення [6]

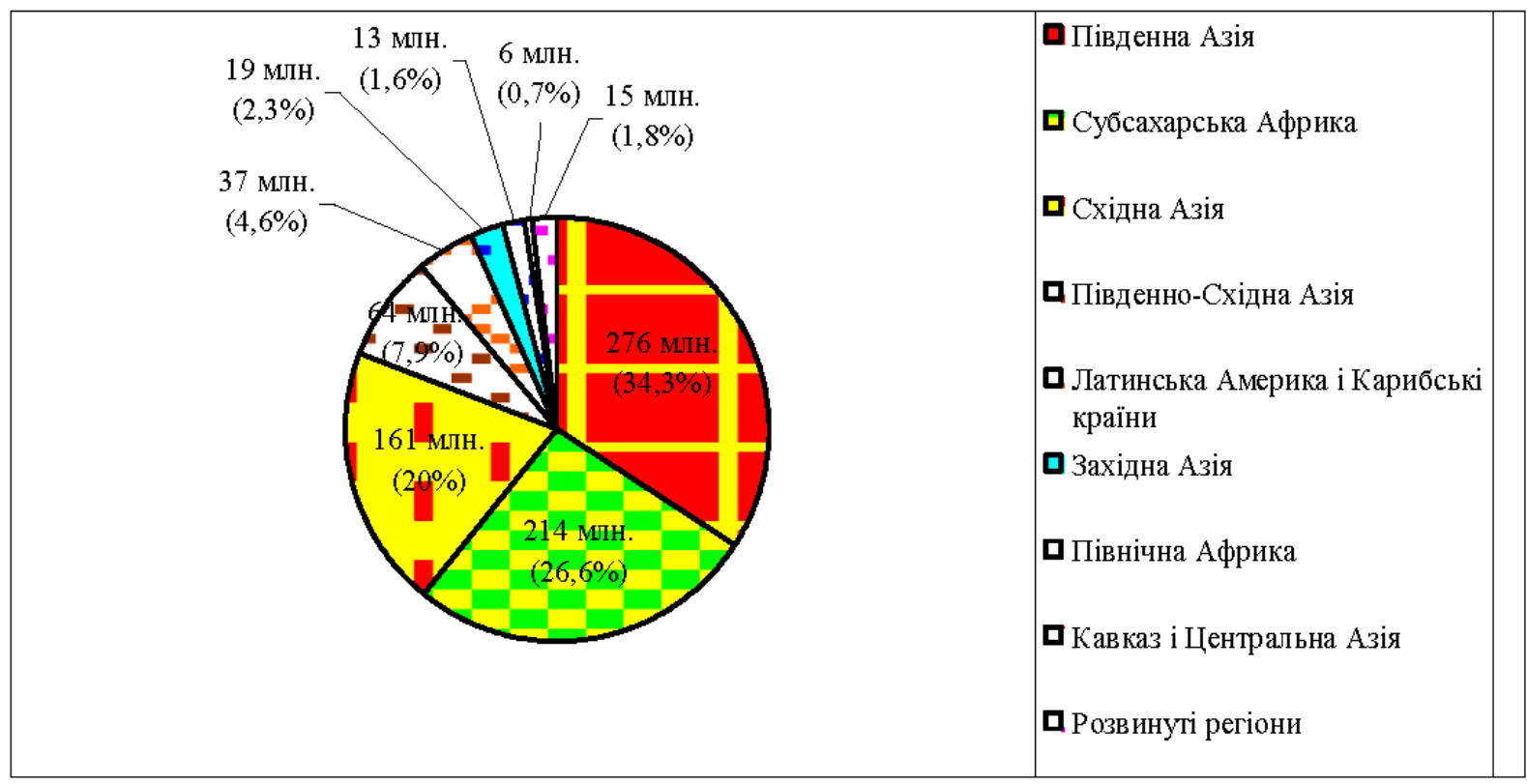

Рис.3. Чисельність осіб, які недоїдають, в регіонах світу від загальної кількості голодуючих у світі [6]

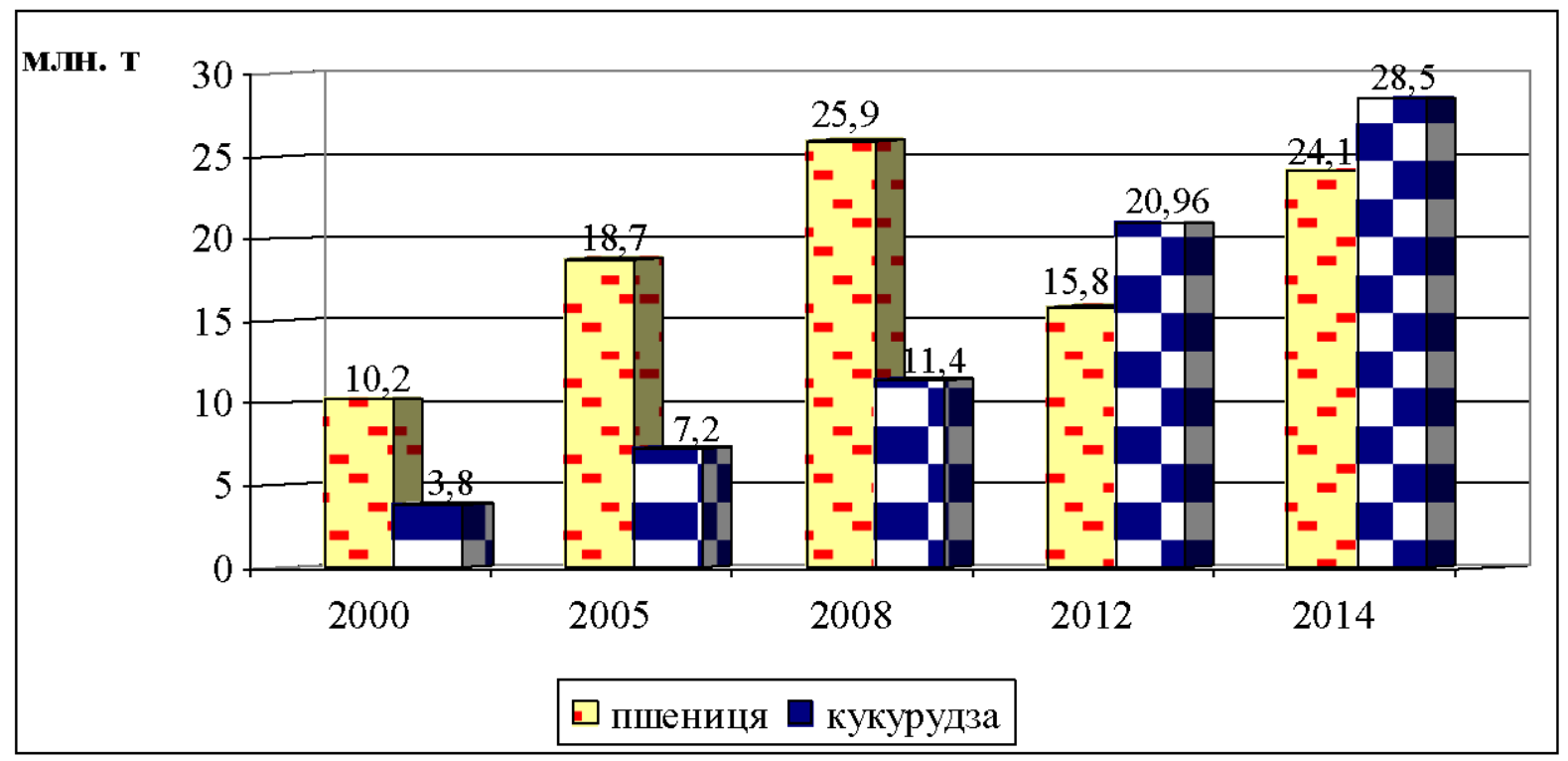

Рис.4. Виробництво пшениці і кукурудзи в Україні протягом 2000-14 рр., млн. т [5] 
3 них (Колумбія, Венесуела, Перу) був на рівні північноафриканських країн (табл. 1).

Дані щодо обсягів виробництва і споживання пшениці і кукурудзи у 2013 і 2013-14 рр. свідчать про неспроможність більшості країн, що розвиваються, внаслідок відсутності в них придатних для вирощування сільгоспкультур земель і стрімкого збільшення чисельності населення, виробляти необхідну для споживання кількість продовольства та про повну їхню залежність від імпорту зерна.

Так, у 2013 р. 6 азійських та південноамериканських країн споживали виключно імпортну пшеницю, 2 країни Азії та Північної Африки - імпортну кукурудзу. При цьому, деякі азійські, африканські і південноамериканські країни виробляли 3, 11, 13 і $16 \%$ пшениці від загального обсягу їі споживання. Країни Північної Африки (Алжир, Туніс, Сгипет), Близького Сходу (Ірак) i Латинської Америки (Мексика і Бразилія) забезпечували власні потреби пшеницею приблизно на $30-50 \%$ від загального обсягу її споживання.

Такий же рівень забезпечення своїх потреб кукурудзою мали Іран, Колумбія, Сгипет, Перу і Венесуела. Менше 10\% від спожитої кількості кукурудзи виробляли Південна Корея, Малайзія і Марокко (табл. 1).

Недостатні обсяги виробництва зерна у країнах Африки, Азії, Латинської Америки призводять до недоїдання значної кількості населення світу. За останніми оцінками ФАО в 2012-2014 рр. у світі 805,3 млн. чол. (11,3\%) хронічно недоїдали. Більшість 3 них - 790,7 млн. чол. - проживають у країнах, що розвиваються. Сьогодні в цих країнах 13,5\% населення (майже кожен восьмий) не отримують достатньої кількості продовольства. Кожна п'ята людина потерпає від хронічного недоїдання в країнах Африки i Карибського басейну, кожна четверта- в Субсахарській Африці (рис. 2).

Із загальної кількості голодуючих осіб (790,7 млн.), 65,3\% населення проживає в країнах Азії, $28,2 \%$ - в Африці. Найбільшу частку осіб, які недоїдають мають країни Південної та Східної Азії і Субсахарської Африки. У цих регіонах проживає більше $75 \%$ населення світу, яке недоїдає (рис. 3).

Дві третини (65\%) всіх голодуючих живуть в 11 країнах світу (Індії, Китаї, Пакистані, Ефіопії, Бангладеш, Індонезії, Танзанії, В'єтнамі, Філіппінах, Нігерії та Кенії). 3 цієї кількості майже 50\% проживають в 3 країнах - Індії, Китаї і Пакистані (табл. 2).

Враховуючи значний природно-ресурсний потенціал, Україна має великі можливості у подоланні продовольчої проблеми в світі. Україна постійно нарощує виробництво стратегічно важливих продовольчих сільгоспкультур у світі - пшениці і кукурудзи. Про це зокрема свідчить дані рисунка 4.

Вже нині Україна експортує зерно у 90 країн світу. Протягом наступного десятиріччя наша держава, за оцінками експертів, завдяки збільшенню врожайності основних сільгоспкультур має можливість збільшити виробництво зернових до 120 млн. і вийти на друге місце в світі за експортом зернових.

На нинішньому етапі розвитку світової економіки в Україні існують перспективи щодо завоювання позицій на продовольчих ринках країн Східної та Південно-Східної Азії, Близького Сходу і Північної Африки.

Однак, на жаль, нині Україна не повністю використовує свій експортний потенціал. Про це свідчать обсяги експорту пшениці і кукурудзи до країн Східної та Південно-Східної Азії, їхнього споживання та імпорту (табл. 3).

Так, 2013 р. загалом до країн Азії експортувалося лише від 0,3 (Іран) до 7,1\% (Філіппіни) загальних обсягів споживання ними пшениці і від 0,9 (Іран) до 12\% (Бангладеш і Філіппіни) загальної кількості їі імпорту. Досить незначними $(0,3-10,2 \%$ від загальної кількості споживання) були і обсяги поставок пшениці до країн Північної та Східної Африки.

Однак країни Східної і Південно-Східної Азії, зважаючи на обсяги споживання та імпорту ними зерна, в майбутньому можуть стати доволі перспективними ринками збуту української пшениці. Так, у 2013 р. 5 країн цих регіонів (Японія, Індонезія, Філіппіни, Бангладеш і Таїланд) сумарно споживали пшениці у кількості, що дорівнює обсягам iï споживання у Туреччині (22,5 млн. т), а імпортували в обсязі (14,2 млн. т), що більш як втричі перевищує показник останньої (4,2 млн.) і майже в 1,4 разиЄгипту (10,5 млн.) та в 1,6 рази- Китаю (8,7 млн.). Крім того, Індонезія, Японія і Філіппіни споживали пшениці загалом в обсязі, що характерний для

Таблиця 2

Світ. Країни з найбільшою кількістю осіб, які недоїдають

\begin{tabular}{|l|c|c|}
\hline & $\begin{array}{l}\text { Кількість } \\
\text { осіб, які } \\
\text { недоїдють, } \\
\text { млн. чол. }\end{array}$ & $\begin{array}{l}\text { \% від } \\
\text { загальної } \\
\text { кількості }\end{array}$ \\
\hline Світ & 805,3 & 100,0 \\
\hline Iндія & 190,7 & 23,7 \\
\hline Китай & 150,8 & 18,7 \\
\hline Пакистан & 39,6 & 4,9 \\
\hline Ефіопія & 32,9 & 4,1 \\
\hline Бангладеш & 26,2 & 3,3 \\
\hline Індонезія & 21,6 & 2,7 \\
\hline Танзанія & 17 & 2,1 \\
\hline В'єтнам & 11,9 & 1,5 \\
\hline Філіппіни & 11,3 & 1,4 \\
\hline Нігерія & 11,2 & 1,4 \\
\hline Кенія & 10,8 & 1,3 \\
\hline Уганда & 9,7 & 1,2 \\
\hline Північна Корея & 9,3 & 1,2 \\
\hline М’янма & 8,9 & 1,1 \\
\hline Ірак & 7,9 & 0,98 \\
\hline Афганістан & 7,5 & 0,9 \\
\hline Мозамбік & 7,2 & 0,89 \\
\hline
\end{tabular}

Складено за [6] 
Ірану (16,7 млн. т), а імпортували в кількості (15,3 млн.), що в 2,5 рази перевищує показник цієї країни (6 млн.).

Перспективними для експорту Україною кукурудзи можуть стати ринки східно- і південносхідноазійських країн. Обсяг споживання кукурудзи лише в одній Індонезії у 2013 р. становив понад 20 млн. т (на 1,5 млн. т більше, ніж в Індіï), а кількість спожитої кукурудзи в Японії (майже 15 млн. т), В’єтнамі (7 млн. т), Філіппінах (близько 8 млн.) і Південній Кореї (понад 9 млн.) був вищим, ніж у Туреччині (6,4 млн. т), Ірані (5,4 млн.) та Пакистані (4,4 млн.).

При цьому досить значними (майже 10 та 15 млн. т) були обсяги імпорту цього зерна в Південній Кореї та Японії, а Малайзія, Індонезія та Філіппіни разом взяті завозили стільки, скільки імпортує Китай (7,7 млн. т).

Ще одним потенційним ринком збуту української пшениці і кукурудзи є країни Північної і Східної Африки. Лише один Єгипет у 2013 р. споживав 19 млн. т пшениці та 13 млн. т кукурудзи, а імпортував 10,5 млн. т пшениці та 8 млн. кукурудзи. Крім того, значними (близько 9 і 10 та більше 4 і 7 млн. т) були обсяги споживання та імпорту пшениці в Марокко i

Алжирі [3].

На думку фахівців, формування зовнішньоекономічної стратегії АПК України має здійснюватися із врахуванням принципу соціальної ефективності розвитку агросектору України (здатності задовольнити потреби населення в основних продуктах харчування в межах раціональних норм, затверджених MO3 України). Соціальні чинники, зокрема рівень споживання основних харчових продуктів на душу населення, нині набувають особливої уваги, оскільки, за різними експертними оцінками, в Україні проживають до 15 млн. громадян, які недоїдають (близько 1/3 ii загальної кількості населення). Із них майже третина отримує доходи, нижчі мінімального прожиткового рівня [2].

Низький рівень доходів населення і падіння його життєвого рівня призвели до відставання фактичних обсягів споживання деяких видів продукції від необхідних норм. Так, 2013 р. населення України споживало лише 70\% необхідної кількості м'яса i м'ясних продуктів, 58\%- молока і молочних продуктів, 63\%- плодів, ягід і винограду, 73\%риби і рибних продуктів.

При цьому, у 18 регіонах України споживання

Таблиця 3

Споживання, імпорт країнами світу та експорт Україною пшениці і кукурудзи

\begin{tabular}{|c|c|c|c|c|c|c|c|c|c|c|}
\hline & \multicolumn{5}{|c|}{ Пшениця } & \multicolumn{5}{|c|}{ Кукурудза } \\
\hline & $\begin{array}{c}\text { Спожи- } \\
\text { вання, } \\
\text { млн. т }\end{array}$ & $\begin{array}{c}\text { Імпорт, } \\
\text { млн. т }\end{array}$ & $\begin{array}{l}\text { Експорт } \\
\text { Україною } \\
\text { (імпорт } 3 \\
\text { України), } \\
\text { млн. т }\end{array}$ & $\begin{array}{l}\text { \% до } \\
\text { загально- } \\
\text { го спожи- } \\
\text { вання } \\
\text { країнами }\end{array}$ & $\begin{array}{l}\text { \% до } \\
\text { загально- } \\
\text { го } \\
\text { імпорту } \\
\text { країнами }\end{array}$ & $\begin{array}{c}\text { Спожи- } \\
\text { вання, } \\
\text { млн. т }\end{array}$ & $\begin{array}{c}\text { Імпорт, } \\
\text { млн. т }\end{array}$ & $\begin{array}{l}\text { Експорт } \\
\text { Україною } \\
\text { (імпорт з } \\
\text { України), } \\
\text { млн. т }\end{array}$ & $\begin{array}{l}\text { \% до } \\
\text { загально- } \\
\text { го спожи- } \\
\text { ван ня } \\
\text { країнами }\end{array}$ & $\begin{array}{l}\text { \% до } \\
\text { загально- } \\
\text { го імпорту }\end{array}$ \\
\hline Азія & 363,2 & 75,7 & 3,49 & 0,96 & 4,6 & 333,1 & 56,8 & 6,37 & 1,9 & 11,2 \\
\hline Китай & 125,4 & 8,7 & - & - & - & 209,1 & 7,7 & 0,11 & 0,05 & 1,4 \\
\hline Пакистан & 24,4 & 0,6 & 0,16 & 0,7 & 2,7 & 4,4 & - & - & - & - \\
\hline Iран & 16,7 & 6 & 0,055 & 0,33 & 0,92 & 5,4 & 4,5 & 1,42 & 26,3 & 31,6 \\
\hline Туреччина & 22,5 & 4,2 & 0,13 & 0,6 & 3,1 & 6,4 & 1,2 & 0,5 & 7,8 & 41,7 \\
\hline Бангладеш & 3,7 & 2,8 & 0,34 & 9,2 & 12,1 & - & - & - & - & - \\
\hline Таїланд & 2 & 2 & 0,38 & 19 & 19 & 4,4 & 0,2 & - & - & - \\
\hline B'єтнам & - & - & 0,1 & - & - & 7 & 2 & 0,003 & 0,04 & 0,15 \\
\hline Малайзія & - & - & 0,029 & - & - & 3,8 & 3,8 & 0,07 & 1,8 & 1,8 \\
\hline Індонезія & 7 & 7,4 & 0,27 & 3,9 & 3,6 & 21,3 & 3,3 & - & - & - \\
\hline Філіппіни & 3,4 & 2 & 0,24 & 7,1 & 12 & 7,8 & 0,5 & - & - & - \\
\hline Японія & 6,4 & 5,9 & 0,27 & 4,2 & 4,6 & 14,8 & 15,1 & 1,25 & 8,4 & 8,3 \\
\hline $\begin{array}{l}\text { Південна } \\
\text { Корея }\end{array}$ & 4,3 & 4,2 & 0,12 & 2,8 & 2,9 & 9,3 & 9,8 & 1,31 & 14,1 & 13,4 \\
\hline Африка & 65,8 & 44,2 & 4,16 & 6,3 & 9,4 & 83,7 & 18,1 & 3,08 & 3,7 & 17 \\
\hline Марокко & 8,9 & 4,2 & 0,2 & 2,2 & 4,8 & 2,2 & 2 & 0,026 & 1,2 & 1,3 \\
\hline Алжир & 9,7 & 7,5 & - & - & - & 3,3 & 3,5 & 0,049 & 1,5 & 1,4 \\
\hline Туніс & 3 & 2 & 0,26 & 8,7 & 13 & - & - & 0,26 & & \\
\hline Сгипет & 19,2 & 10,5 & 1,96 & 10,2 & 18,7 & 13,2 & 8 & 2,45 & 18,6 & 30,6 \\
\hline Ефіопія & 4,5 & 0,9 & 0,12 & 2,7 & 13,3 & 7 & 0,1 & - & - & - \\
\hline Кенія & - & - & 0,46 & - & - & 4,1 & 0,6 & - & - & - \\
\hline Нігерія & 3,5 & 4,5 & 0,01 & 0,29 & 0,22 & 9,9 & 0,2 & - & - & - \\
\hline
\end{tabular}

Складено і розраховано за [3; 7] 
м'яса і м'ясних продуктів становило 53-69\% необхідної норми, плодів, ягід і винограду - 45-60\%. Крім того, у 8 областях і АРК споживання молока і молочних продуктів було на рівні 49-56\% раціональної норми, в 11 областях споживання риби і рибних продуктів було на рівні 43-72\% від необхідної норми [4].

Низький рівень споживання продукції тваринництва, а також плодівництва протягом останніх років внаслідок недостатньої купівельної спроможності населення призвів до зменшення виробництва цих видів продукції і ненасиченості ними внутрішнього продовольчого ринку.

Тому надзвичайно важливим завданням для України, яке допоможе їй збільшити обсяги виробництва основних видів продукції, задовольнити внутрішні потреби у продуктах харчування i реалізувати потенціал світової «житниці» $\epsilon$ подолання негативних внутрішніх та зовнішніх факторів впливу на розвиток аграрного сектору i формування продовольчої бази та продовольчої безпеки країни.

Основними негативними чинниками впливу на сучасний стан агросектору країни є відсутність чіткої стратегії його розвитку; законодавча неврегульованість розвитку цієї галузі; відсутність в держави інфраструктури та системи підтримки національних виробників.

Основними зовнішніми негативними чинниками впливу на сучасний i розвиток аграрного сектору України і формування їі продовольчої бази та продовольчої безпеки є: недостатня проробленість питань щодо захисту національного виробника при підготовці та підписанні Україною міжнародних угод в сфері торгівлі сільгосппродуктами; відсутність державної стратегії реалізації експортного потенціалу сільгоспвиробництва; слабо організована робота щодо реалізації потенціалу експорту сільгосппродукції на регіональних міжнародних ринках; загрози, спричинені спеціалізацією України на експорті грунтовиснажуючих культур. Крім того, ефективний розвиток i функціонування вітчизняного АПК передбачає залучення Україною близько \$100 млрд. іноземних інвестицій для оновлення матеріальнотехнічної бази підприємств агросектору, впровадження сучасних технологій виробництва, зберігання і транспортування продукції, у розвиток логістичної інфраструктури зернового та інших секторів АПК [1].

Ключовим ресурсом, який зацікавить інвесторів, є майбутня продуктивність землі та аграрної інфраструктури. На думку багатьох аналітиків Світового банку, Продовольчої та сільськогосподарської організації (ФАО) і низки фондів, при правильному підході до інвестиційної політики протягом наступних 5-7 років Україна вироблятиме 120 млн. т зернових і 7 млн. т м'яса.

Висновки. У сьогоднішніх умовах у світі спостерігається дефіцит продовольства. Тому Україна має значний потенціал експорту сільгосппродукції, який не використовується повною мірою. Реалізація потенціалу «житниці» Європи та світу потребує складного комплексу зусиль. Сільське господарство України потребує якісних змін, які дозволять збільшити його економічну, соціальну i екологічну ефективність виробництва, продуктивність праці, гарантуватимуть продовольчу безпеку України, і підвищать конкурентоспроможність агросектору.

Для нарощування обсягів виробництва i експорту продукції АПК в Україні повинна здійснюватися цілеспрямована державна підтримка основних галузей тваринництва i рослинництва в межах заходів т. зв. «зеленої скриньки». Вона передбачає сприяння структурній перебудові сільськогосподарського виробництва i збуту сільськогосподарської продукції (включаючи ii збирання i переробку), розвиток інфраструктури i удосконалення землекористування, програми регіонального розвитку і забезпечення продовольчої безпеки тощо.

Основними напрямами

підвищення конкурентоспроможності агросектору на внутрішньому і зовнішньому ринках $є$ перехід від дрібнотоварного виробництва сільгосппродукції (особистих підсобних господарств населення) до нових організаційно-правових форм господарювання (кооперативів, сімейних ферм); створення сприятливих передумов для розвитку малого i середнього агробізнесу у сільській місцевості.

Крім того, виконуючи взяті на себе зобов'язання в рамках членства в СОТ, Україні потрібно привести у відповідність 3 європейськими вимогами законодавство щодо безпечності та якості продукції, провести сертифікацію агропідприємств, дотримуватися i застосовувати стандарти якості та безпеки продукції відповідно до міжнародних вимог. Адже експорт якісної сільгосппродукції може принести Україні значні прибутки і підвищити товарний рівень на міжнародних (а саме європейських) ринках.

\section{References:}

1. Čìpko T. Agrarno-virobničij potencìal Ukraïni na tlì svìtovoï prodovol'čoï krizi [Agro-industrial potential of Ukraine in the midst of the global food crisis]. Geografičeskie i geoèkologičeskie issledovaniâ v Ukraine $i$ sopredel'nyh territoriâh: sbornik naučnyh statej [Geographical and geoecological researches in Ukraine and adjacent territories: collection of scientific articles]. General Editorship: B. A. Vahrušev. Simferopol, 2013, T. 1., 570 p. (In Ukrainian).

2. Čopenko V. Golodnij sitomu ne rìvnâ [A full man is no friend to a hungry man]. Dzerkalo tižnâ [The Mirror 
of the Week], \# 23, 27.06-3.07. Access mode: http:/gazeta.dt.ua/ariculture/golodniy-sitomu-ne-rivnya-_.html (In Ukrainian).

3. Food Outlook. Biannual report on global food markets. October 2014. Source://http://www.fao. org/docrep/019/ i3751e/i3751e.pdf

4. Statistical digest "Balances and consumption of basic foodstuffs in Ukraine". Access mode: http://www. ukrstat.gov.ua/ (In Ukrainian).

5. Statistical digest "Agriculture of Ukraine in 2013". Access mode: http:// www.ukrstat.gov.ua/ (In Ukrainian).

6. The food insecurity in the world 2014. Source:// http://www.fao.org/3/a-i4030e.pdf

7. Website of the State Statistics Service of Ukraine. Access mode: http:// www.ukrstat.gov.ua (In Ukrainian). 